\title{
EFFECTIVENESS OF ONLINE LEARNING IN CLASS IV A SD NEGERI MERTASINGA 07 CILACAP
}

\author{
Ida Suryaningsih ${ }^{1}$, Pamujo $^{2}$ \\ ${ }^{1,2}$ Pendidikan Guru Sekolah Dasar, Universitas Muhammadiyah Purwokerto, Indonesia
}

\section{Article Info}

Article history:

Received: 23-07-2021

Revised: 12-08-2021

Published: 30-09-2021

\section{Keywords:}

Effectiveness

Online Learning

ABSTRACT

The COVID-19 pandemic in Indonesia affected several sectors, one of which was the education sector. With the outbreak, the government issued an online learning policy as an alternative to face-to-face learning. Online learning policies will affect the effectiveness of learning due to the lack of readiness of schools, teachers, and students. The purpose of this study was to determine the effectiveness of online learning during the pandemic. This subject were IV graders A SD Negeri Mertasinga 07 Cilacap. This research type was a mixed quantitative qualitative research. Data collection techniques were obtained by observation, interviews, and questionnaire. The results of the study revealed that online learning could replace face-to-face learning during the pandemic and could run effectively if it was supported by sufficient devices and a stable internet connection as well as the teacher's skill to use various online learning media such as WhatsApp, Google Classroom and Google Meet to attract attention and reduce student boredom.
\end{abstract}

This is an open access article under the CC BY-SA license.

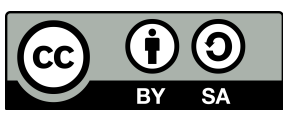

\section{Corresponding Author:}

Ida Suryaningsih,

Pendidikan Guru Sekolah Dasar, Universitas Muhammadiyah Purwokerto,

Email: idasuryaningsih049@gmail.com

\section{INTRODUCTION}

The Covid-19 pandemic that has hit Indonesia since March 2020 has affected many sectors, one of which is the education sector. Government policies are urgently needed in breaking the chain of the spread of the Covid-19 virus, so the government issued one policy, namely the policy regarding the implementation of online learning (Covid-19 2020 Handling Committee). Learning activities in 2020 are very different where learning should be carried out in a face-to-face situation between teachers and students, but now learning can only be done indirectly by using online learning such as using multimedia technology, virtual classes, CDs, ROMs, streaming video, voicemail, email and telephone conferences (Arsyad, 2011; Kuntarto, 2017). By using online learning, students are required to be able to learn independently with the help of their parents. To support the online learning process, it is necessary to have a learning process, learning media and teaching materials that have been adapted to the characteristics of students during the learning process.

Learning media used by teachers during online learning is a new thing, these learning media include Google Classroom, WhatsApp Groups and Google Meet (Wahyuni, 2021). As for the teaching materials used to support the learning media, namely, Video and Powerpoint. The learning media and teaching materials above are expected to be indicators to increase the attractiveness of children to study better and harder and to make it easier for students to understand the material. With the Covid-19 pandemic, which requires educational institutions to replace face-to-face learning and replace it with online learning methods, there is an opportunity for research related to whether online learning can be effective during the pandemic. 
So far there have been several studies conducted to see how online learning is carried out during the Covid-19 pandemic, as done by Mustakim (2020) showing the results that online learning is effective because of the use of various learning media (WhatsApp Group, Youtube, Google Classroom, Instagram, and Zoom). Furthermore, research conducted by Hamdani \& Priatna (2020) related to effective online learning which was influenced by eight indicators, namely the convenience of learning during the pandemic, teacher digital literacy skills, the level of student adaptation to learning, adequacy of devices, internet connection, learning costs (Warsita, 2011). online, application convenience level, and post-pandemic online commitment. Meanwhile, research conducted by Aziz (2020) shows that online learning does not work effectively because students have difficulty understanding the material.

Based on the studies above, it is important to conduct research that can provide an overview regarding the effectiveness of online learning in elementary schools with the teacher's ability to carry out the learning process, use of online learning media and various teaching materials such as what was done by class IV A homeroom teachers SD Negeri Mertasinga 07. Researchers focus on the learning process, using various learning media and teaching materials to streamline online learning. This research is expected to be useful in providing additional information regarding the description of the effectiveness of the implementation of online learning in elementary schools, especially grade IV A SD Negeri Mertasinga 07 Cilacap.

\section{RESEARCH METHOD}

The research method used in this study is a mixture of quantitative and qualitative. The subjects of this study were all grade IV A students at SD Negeri Mertasinga Cilacap for the academic year 2020/2021 a total of 25 students. This research was conducted in the even semester 2020/2021 academic year in May 2021. The data collection techniques and instruments in this research used questionnaires, observations and interviews (Sugiyono, 2016). This study uses an online questionnaire using a google form. The questionnaire for student responses is a closed questionnaire consisting of 23 statements, while the online learning assessment questionnaire by the principal is a closed questionnaire with 20 statements. Both questionnaires used a Likert Scale. Questionnaire Test the requirements of the questionnaire instrument consisting of validity and reliability tests using the help of SPSS version 16. Testing the validity of each item by comparing $r$ count with $r$ table at a significant level of 5\%. Instrument items are considered valid if $r$ count is greater than $r$ table and is considered invalid if $r$ count is less than $r$ table. The value of $r$ table with the number of respondents ( $n$ ) 25 is 0.396 . Based on the results of the validity test with $\mathrm{n}=25,=5 \%, \mathrm{r}$ table $=0.396$ and is positive. The reliability test shows the extent to which the data can be trusted. To test the reliability of the study using the Alpha Cronbach formula. The formula is used to find the reliability of the instrument whose scores are not 1 and 0 . In the reliability test if the Cronbach's alpha value is $i 0.70$ then the instrument is said to be reliable or trustworthy. With the help of SPSS 16 , the reliability test results obtained are 0.888 which means reliable or trustworthy. After obtaining the value of each item, it will then be determined and calculated the type of descriptive percentage then interpreted into sentences and analyzed descriptively using data analysis techniques according to Miles and Huberman.

\section{RESULT AND DISCUSSION}

Online learning can be said to be effective if the learning process goes well. The results of filling out the questionnaire responses for grade IV A students at SD Negeri Mertasinga 07 Cilacap during online learning and a questionnaire on the effectiveness of online learning filled out by the principal of SD Negeri Mertasinga 07 Cilacap showed that $24 \%$ of students said they strongly agreed, $72 \%$ said they agreed, $4 \%$ said they did not agree. regarding ownership of adequate devices (HP/Laptop) and $8 \%$ of students said they strongly agreed, $84 \%$ of students said they agreed, $8 \%$ said they did not agree with getting easy internet access around their homes. Thus, more students use adequate devices and have easy access to the internet during online learning. The selection of the right online learning media will make students more interested and not feel bored in learning. The media used for online learning vary, as used by the homeroom teacher for grade IV A SD Negeri Mertasinga 07 Cilacap, namely WhatsApp Groups, Google Classroom and Google Meet.

The results of filling out the questionnaire responses of grade IV A students at SD Negeri Mertasinga 07 Cilacap during online learning and a questionnaire on the effectiveness of online learning filled out by the principal of SD Negeri Mertasinga 07 Cilacap related to the use of online learning media 7 seen as many as $16 \%$ of students said they strongly agreed, $76 \%$ of students said agree and $8 \%$ of students say they disagree regarding online learning that teachers carry out using learning applications such as WhatsApp Groups, Google 
Classroom and Google Meet. The assessment carried out by the principal of the teacher's school got a percentage of $100 \%$ being able to use more than two online learning media when learning online. Based on the results of interviews with classroom teachers, teachers use three online learning media aimed at attracting students' attention and reducing students' boredom during online learning. The use of WhatsApp Groups, Google Classroom and Google Meet is done alternately. In terms of the convenience of using WhatsApp Groups, Google Classroom, and Google Meet media, $12 \%$ of students said they strongly agreed, $68 \%$ of students said they agreed and $20 \%$ of students said they did not agree. Based on the following percentage results, more students feel comfortable using the three learning media provided by the teacher for online learning. Regarding applications that are easy to use when learning WhatsApp applications get a percentage of $92 \%$, Google Classroom gets a percentage of $92 \%$ and Google Meet gets a percentage of $84 \%$. Based on the following percentage results, it is easier for students to use text-based online learning media than virtual video-based online learning media.

The use of appropriate teaching materials for online learning media greatly influences the understanding of the material received by students. The results of filling out the questionnaire responses of grade IV A students at SD Negeri Mertasinga 07 Cilacap during online learning and a questionnaire on the effectiveness of online learning filled out by the principal of SD Negeri Mertasinga 07 Cilacap related to the use of teaching materials seen $96 \%$ of students said the learning videos provided by the teacher when online learning were interesting , $92 \%$ of students said the material in the learning video was easy to understand, and $96 \%$ of the students said that the material contained in the learning video was complete. While as many as $92 \%$ of students said the Powerpoint slides given by the teacher were interesting, $84 \%$ of students said that the PowerPoint slides were easy to understand and $100 \%$ agreed that the materials in the PowerPoint slides were complete. Based on the results of the principal's assessment, teachers get a percentage of $100 \%$ in providing video teaching materials and power point slides that are interesting, easy to understand and complete. stated that the material given in the video was easier to understand than in the powerpoint slide. However, for the completeness of the material, students state that the material in the power point slide is more complete than the material in the video because the explanation of the material in the video is in oral form so that it can be shortened if the description of the material is written in power point, the teacher can make the material completely and in detail.

This research is relevant to the results of Mustakim (2020) which says that online learning is effectively carried out with a percentage value of $70 \%$ effective learning with teachers using five online learning media and the research results of Hamdani \& Priatna (2020) which show the level of effectiveness of online learning around $66.79 \%$ which is influenced by eight factors such as the convenience of learning during the pandemic, the teacher's digital literacy ability, the level of adaptation of students to learning, the adequacy of devices, internet connections, online learning costs, the level of convenience of learning applications and post-pandemic online commitments.

\section{CONCLUSION}

First, online learning in Class IV A SD Negeri Mertasinga 07 Cilacap can run effectively because it is supported by adequate devices, smooth internet connection and comfort during the online learning process related to media and teaching materials selected by the teacher. Second, as many as $92 \%$ of students feel comfortable using WhatsApp and Google Classroom in online learning and students are more interested in learning using video teaching materials and powerpoint slides. Third, as many as $88 \%$ of students said that online learning could replace face-to-face learning during a pandemic and that online learning was effective, as evidenced by the average result of Semester II UAS for grade IV A students at SD Negeri Mertasinga 07 Cilacap amounting to 83.60 .

Principal of SD Negeri Mertasinga 07 Cilacap participates in improving the learning system that supports the school during the pandemic period so that it will be even better in the future. Second, Class IV A teachers at SD Negeri Mertasinga 07 Cilacap can improve their ability to use online learning media and other and up-to-date teaching materials to improve the new learning atmosphere during the pandemic so that students will be easily interested in the learning carried out.

\section{REFERENCES}

Arsyad, A. (2011). Media Pembelajaran. Jakarta: PT Raja Grafindo Persada. 
Aziz, A. (2020). Efektivitas Pembelajaran Daring Saat Menghadapi Virus Corona. Karawang: Universitas Singaperbangsa Karawang.

Hamdani, A. R., \& Priatna, A. (2020). Efektifitas Implementasi Pembelajaran Daring (Full Online) Dimasa Pandemi Covid-19 Pada Jenjang Sekolah Dasar Di Kabupaten Subang. Didaktik: Jurnal Ilmiah PGSD STKIP Subang, 6(1), 1-9.

Kuntarto, E. (2017). Keefektifan Model Pembelajaran Daring Dalam Perkuliahan Bahasa Indonesia di Perguruan Tinggi. Journal Indonesian Language Education and Literature, 3(1), 99-110. doi:10.24235/ileal. v3i1.1820

Mustakim, M. (2020). EFEKTIVITAS PEMBELAJARAN DARING MENGGUNAKAN MEDIA ONLINE SELAMA PANDEMI COVID-19 PADA MATA PELAJARAN MATEMATIKA. Al asma : Journal of Islamic Education, 2(1), 1. doi:10.24252/asma.v2i1.13646

Sugiyono. (2016). Metode Penelitian dan Pengembangan (Research and Development). Bandung: Alfabeta.

Wahyuni, V. N. (2021). Efektifitas penggunaan google meet dalam pembelajaran daring terhadap peningkatan hasil belajar siswa kelas V SD Al Islam Plus Krian Sidoarjo (Doctoral dissertation, UIN Sunan Ampel Surabaya).

Warsita, B. (2011). Pendidikan Jarak Jauh. Bandung: PT Remaja Rosdakarya. 